\title{
PENGARUH LAYANAN BIMBINGAN KELOMPOK TERHADAP PERILAKU PROSOSIAL SISWA KELAS VII DI SMP NEGERI 22 KOTA BENGKULU
}

\author{
Tri Wulandari, I Wayan Dharmayana, Vira Afriyati \\ Prodi Bimbingan dan Konseling Fakultas Keguruan dan Ilmu Pendidikan \\ Universitas Bengkulu \\ Triwulandari1710@gmail.com,dharmayana@unib.ac.id,vira_afriyati@unib.ac.id
}

\begin{abstract}
ABSTRAK
Penelitian ini bertujuan untuk mendeskripsikan pengaruh layanan bimbingan kelompok terhadap perilaku prososial siswa kelas VII. A SMP Negeri 22 Kota Bengkulu. Metode yang digunakan yaitu ekperimen one group pretest-posttest design. Subjek penelitian ini yaitu 12 siswa kelas VII. A yang dipilih menggunakan teknik purposive sampling. Pengumpulan data pada penelitian ini menggunakan skala perilaku prososial. Hasil penelitian ini menunjukkan 12 siswa kelas VII.A meningkat setelah diberikan layanan bimbingan kelompok. Nilai $\mathrm{z}=-3063,(\mathrm{p}<0,05)$ ini berarti menunjukkan ada pengaruh yang signifikan layanan bimbingan kelompok terhadap perilaku prososial siswa Kelas VII.A SMP Negeri 22 Kota Bengkulu.
\end{abstract}

Kata kunci: perilaku prososial, layanan bimbingan kelompok

\section{THE EFFECT OF GROUP COUNSELING SERVICES ON THE STUDENTS' PROSOCIAL BEHAVIOR OF CLASS VII AT SMPN 22 BENGKULU}

\begin{abstract}
ABSTRACK
The purpose of this study is to describe the effect of counseling services on the students' prosocial behavior of class VII at SMPN 22 Bengkulu. The method was pre experiment with one group pretest-posttest design Subject of this study was 12 students of VII.A class that chosen by using purposive technique sampling, data collected by prosocial behavior scale. The result showed that 12 students of VII.A class was increase after given group scounseling services. The value of $\mathrm{z}=-3063(\mathrm{p}<0.05)$. It means that there was significant effect of group counseling services on the prosocial behavior students at class VII SMPN 22 Bengkulu.
\end{abstract}

Keywords: prosocial behavior, group counseling services 


\section{Pendahuluan}

Manusia sebagai makhluk sosial selalu berinteraksi dengan lingkungan dimana dia berada. Agar interaksi dapat berjalan dengan baik, diperlukan beberapa penguasaan keterampilan dan kemampuan yang dimiliki oleh manusia.

Manusia secara hakiki merupakan makhluk sosial yang senantiasa memerlukan orang lain untuk dapat memenuhi kebutuhan hidupnya, baik kebutuhan fisiologis maupun kebutuhan psikologis (Gerungan, 2010: 26). Hubungan sosial yang terjalin akan mempengaruhi kelangsungan hidup manusia yang saling membutuhkan satu sama lain.

Kelebihan manusia sebagai makhluk sosial yaitu kesediannya memberikan pertolongan, mengulurkan tangan terhadap keluarga, kelompok maupun dengan komunitasnya, bahkan siap menolong orang tidak dikenal dari etnis atau bangsa lain tanpa pamrih. Tindakan menolong ini menggambarkan manusia sebagai makhluk sosial yang tidak egois serta mempunyai kemampuan memberikan bantuan kepada orang lain.

Menurut Rhushton (dalam Sears dkk, 1991: 47) bahwa perilaku prososial berkisar dari tindakan altruisme yang tidak mementingkan diri sendiri sehingga tindakan menolong sepenuhnya dimotivasi oleh kepentingan diri sendiri. Saat seseorang memutuskan untuk menolong orang lain, itu disebabkan karena hanya ingin membuat orang yang diberikan pertolongan terkesan dengan pertolongan tersebut. Selain seseorang memutuskan untuk menolong orang lain itu dimotivasi oleh perasaan empati yang tulus.

Baron dan Byrne (2005: 92) menyatakan, "suatu tindakan menolong yang menguntungkan orang lain tanpa harus menyediakan suatu keuntungan langsung pada orang yang melakukan tindakan tersebut, dan mungkin bahkan melibatkan suatu risiko bagi orang yang menolong". Pernyataan tersebut menegaska n bahwa perilaku prososial dilakukan individu untuk membantu individu lain tanpa mementingkan diri sendiri. Penggabungan aspek perilaku prososial yang dilakukan peneliti dikarenakan sesuai dengan permasalahan yang ada, empat aspek dari Eisenberg dan Mussen (dalam Dayakisni \& Hudaniah, 2009: 155) seperti kerjasama, berbagi, menolong dan mempertimbangkan hak dan kesejahteraan orang lain dan satu aspek dari sampson (dalam Darmadji, 2011: 31) yaitu peduli.

Pada kondisi saat ini perilaku prososial sangat diperlukan dalam kehidupan bermasyarakat karena perilaku 
sosial sangat penting dimiliki oleh setiap individu termasuk siswa yang berada di sekolah menengah pertama. Siswa yang sedang memasuki masa remaja tentunya memiliki permasalahan sosial yang lebih kompleks dibandingkan dengan masa sebelumnya. Hal ini disebabkan karena pada masa remaja individu sudah memasuki dunia pergaulan yang lebih luas dimana pengaruh teman dan lingkungan sosial akan menuntut remaja untuk beradaptasi.

Masa remaja merupakan masa transisi dari masa kanak-kanak menuju masa dewasa. Sarwono (2009: 11) berpendapat bahwa batas usia remaja menurut WHO yaitu 10-20 tahun, yaitu remaja awal 10-14 tahun dan remaja akhir 15-20 tahun, sedangkan batasan usia remaja untuk masyarakat Indonesia menggunakan 11-24 tahun dan belum menikah. Berdasarkan definisi di atas, maka siswa kelas VII SMP Negeri 22 Kota Bengkulu termasuk pada usia remaja karena berada pada kisaran usia 12-14 tahun.

Peneliti melakukan observasi selama magang tiga di SMP Negeri 22 Kota Bengkulu selama dua bulan. Hasilnya menunjukkan bahwa di kelas VII A masih dijumpai beberapa siswa yang tingkat kepedulian terhadap teman masih kurang, siswa kurang dapat berbagi dengan teman yang sedang mengalami kesulitan, misalnya ada teman yang ingin meminjam alat tulis, namun tidak diberikan dengan alasan takut hilang atau tidak dikembalikan sehingga mereka terkesan pelit,

kurangnya perilaku menolong yang dilakukan siswa, terlihat dari ada teman yang jatuh bukannya dibantu tetapi malah ditertawai siswa juga kurang mampu untuk dapat bekerjasama dalam kelompok, terlihat dari sebagian siswa yang belum bertanggung jawab terhadap kelompok belajar dan diskusi, sehingga kurang mampu mengambil peranan dalam kerja kelompok serta kurang mempertimbangkan hak dan kesejahteraan orang lain dengan menggoda teman yang terlalu serius belajar.

Salah satu peran yang dilakukan peneliti dalam mengatasi rendahnya perilaku prososial siswa kelas VII. A di SMP Negeri 22 Kota Bengkuluadalah dengan cara memberikan pelayanan bimbingan kelompok karena melalui layanan bimbingan kelompok peneliti dapat memanfaatkan dinamika kelompok sebagai pengembangan sosial siswa dalam bekerjasama, berbagi, saling tolongmenolong, peduli terhadap sesama serta dapat mempertimbangkan hak dan kesejahteraan orang lain. 
Berdasarkan fenomena itulah, maka peneliti mencoba untuk memberikan perlakuan melalui layanan bimbingan kelompok untuk membantu masalah siswa, khususnya perilaku prososial. Oleh sebab itulah peneliti mengambil judul "Pengaruh layanan Bimbingan Kelompok Terhadap Perilaku Prososial Siswa Kelas VII. A di SMP Negeri 22 Kota Bengkulu.

\section{Metode Penelitian}

Pada penelitian ini metode penelitiannya adalah desain penelitian quasi eksperimen. Penelitian ini menggunakan pre-eksperimental design dengan jenis one group pre test and post test design. Pengukuran pertama (pre test) dilakukan untuk mengetahui kondisi sampel sebelum diberikan perlakuan yaitu tingkat perilaku prososial siswa sebelum diberikan layanan bimbingan kelompok dan pengukuran kedua (post test) dilakukan untuk mengetahui tingkat perilaku prososial siswa setelah diberikan layanan bimbingan kelompok. Desain tersebut dapat digambarkan sebagai berikut:

\begin{tabular}{|lll|}
\hline 01 & $\mathrm{x}$ & 02 \\
\hline
\end{tabular}

Keterangan:

O1 : Pengukuran pertama atau (pre test), perilaku prososial siswa sebelum diberikan perlakuan yang diukur dengan menggunakan instrumen berupa kuesioner.

X : Perlakuan siswa atau (Treatment), pelaksanaan kelompok mengenai perilaku prososial siswa pada kelas VII A di SMP Negeri 22 Kota Bengkulu.

O2 : Pengukuran kedua atau (posttest),perilaku prososial siswa sesudah di berikan perlakuan berupa layanan bimbingan kelompok mengenai perilaku prososial dengan menggunakan instrumen yang sama pada pengukuran pertama.

Tempat yang digunakan dalam melaksakan penelitian ini adalah kelas VII di SMP Negeri 22 Kota Bengkulu. Penelitian ini dilaksanakan pada semester genap tahun ajaran 2016/2017. Populasi dalam penelitian ini adalah siswa kelas VII jumlah populasi 20 siswa. Sampel penelitian ini adalah 12 orang siswa kelas VII A di SMP Negeri 22 Kota Bengkulu.

Adapun prosedur pengambilan subjek dalam penelitian ini menggunakan purposive sampling.Purposive sampling adalah teknik pengambilan sampel sumber data dengan pertimbangan tertentu Sugiyono (2007: 54) seperti berada dalam satu kelas dan memiliki perilaku prososial yang rendah. 
Tujuan penelitian ini untuk melihat apakah terdapat pengaruh layanan bimbingan kelompok terhadap perilaku prososial siswa.

Variabel bebas $(\mathrm{X})$ dalam penelitian ini adalah layanan bimbingan kelompok. Layanan Bimbingan kelompok adalah suatu kegiatan yang dilakukan oleh sekelompok orang dengan memanfaatkan dinamika kelompok. Artinya semua peserta dalam kegiatan bimbingan kelompok saling berinteraksi, bebas mengeluarkan pendapat, menanggapi, memberi saran dan berinteraksi dan lain sebagainya serta apa yang dibicarakan itu semuanya bermanfaat untuk dirinya peserta yang bersangkutan sendiri dan untuk peserta lainnya.

Variabel Terikat (Y) dalam penelitian ini adalah perilaku prososi siswa. Perilaku prososial merupakan suatu bentuk perilaku yang positif yang dilakukan dengan sukarela tanpa ada paksaan dari orang lain serta atas inisiatif diri sendiri yang dilakukan semata-mata hanya untuk memberikan bantuan atau menolong orang lain tanpa mengharapkan imbalan apapun. Perilaku prososial mencakup tindak seperti kerjasama, berbagi, menolong orang lain, peduli serta mempertimbangkan hak dan kesejahteraan orang lain.

Sebelum angket diberikan kepada responden penelitian, terlebih dahulu dilakukan uji coba alat ukur penelitian kepada 40 orang siswa. Tujuan dilakukan uji coba penelitian adalah untuk mengetahui validitas dan reliabilitas. Validitas konstruk diuji dengan mengetahui nilai $r_{\text {tabel }}$ pada batas tolerasi 0,312 Teknik pengumpulan data pada penelitian ini menggunakan skala prososial. 46 item skala prososial yang valid terdiri dari nomor $1,2,3,4,5,6$, $7,11,12,25,26,27,28,29,30,31$, $32,33,34,35,37,38,40,41,45,47$, $49,50,51,53,54,56,58$, dan 60 sedangkan pada item butir angket yang tidak valid ada 14 butir yaitu nomor 8,10 , $33,36,39,42,43,44,46,48,52,55,57$, dan 59 dari 60 item, dengan cronbact alpha $=0.925$, ini berarti instrumen yang digunakan memiliki tingkat reliabilitas yang tinggi.

Data hasil penelitian ini dianalisis menggunakan Wilcoxon Signed Ranks Test atau 2 test. Indeks corrected item -total correlation yang terendah $0,312-0,672$.

\section{Hasil dan Pembahasan}

Untuk menentukan kategori perolehan skor perilaku prososial, maka peneliti menyusun kriteria-kriteria yang telah ditentukan berdasarkan atribut yang diukur. Kategori interval perolehan skor perilaku prososial adalah sebagai berikut: 
$\mathrm{ST}=$ Sangat Tinggi $(>154)$

$\mathrm{T}=$ Tinggi $(139-153)$

$\mathrm{S}=\operatorname{Sedang}(124-138)$

$\mathrm{R}=\operatorname{Rendah}(93-137)$

$\mathrm{SR}=$ Sangat Rendah $(<92)$

Berdasarkan hasil olah pre-test kuesioner perilaku prososial yang dapat dilihat pada tabel 1 .

Tabel 1.

Frekuensi Pretest Perilaku Prososial

\begin{tabular}{cccc}
\hline $\begin{array}{c}\text { Interv } \\
\text { al } \\
\text { Skor }\end{array}$ & $\begin{array}{c}\text { Katego } \\
\text { ri }\end{array}$ & $\begin{array}{c}\text { Keterang } \\
\text { an }\end{array}$ & $\begin{array}{c}\text { Persenta } \\
\text { se }\end{array}$ \\
\hline 154 & $\begin{array}{c}\text { Sangat } \\
\text { Tinggi }\end{array}$ & 1 & $5 \%$ \\
\hline $\begin{array}{c}139- \\
153\end{array}$ & Tinggi & 4 & $20 \%$ \\
\hline $\begin{array}{c}124- \\
138\end{array}$ & Sedang & 3 & $15 \%$ \\
\hline $\begin{array}{c}93- \\
123\end{array}$ & Rendah & 9 & $45 \%$ \\
\hline$\leq 92$ & $\begin{array}{l}\text { Sangat } \\
\text { Rendah }\end{array}$ & 3 & $15 \%$ \\
\hline Jumlah & $\mathbf{2 0}$ & $\mathbf{1 0 0 \%}$
\end{tabular}

Berdasarkan Tabel di atas menunjukkan tingkat perilaku prososial siswa kelas VII A di SMP Negeri 22 Kota Bengkulu sebelum diberikan layanan bimbingan kelompok terdapat satu orang memiliki tingkat perilaku prososial tergolong sangat tinggi, empat siswa memiliki tingkat perilaku prososial tinggi, tiga orang siswa memiliki tingkat perilaku prososial sedang, sembilan siswa memiliki tingkat perilaku prososial rendah dan tiga siswa tergolong memiliki perilaku prososial sangat rendah 93-123.

Berdasarkan hasil olah posttest kuesioner perilaku prososial yang dapat dilihat pada tabel 2 yaitu :

Tabel 2.

Frekuensi Posttest Perilaku Prososial

\begin{tabular}{cccc}
\hline $\begin{array}{c}\text { Interv } \\
\text { al } \\
\text { Skor }\end{array}$ & $\begin{array}{c}\text { Kualifik } \\
\text { asi }\end{array}$ & $\begin{array}{c}\text { Frekuen } \\
\text { si }\end{array}$ & $\begin{array}{c}\text { Persenta } \\
\text { se }\end{array}$ \\
\hline 154 & $\begin{array}{c}\text { Sangat } \\
\text { Tinggi }\end{array}$ & 6 & $50 \%$ \\
\hline $\begin{array}{c}139- \\
153\end{array}$ & Tinggi & 4 & $33 \%$ \\
\hline $\begin{array}{c}124- \\
138\end{array}$ & Sedang & 2 & $17 \%$ \\
\hline $\begin{array}{c}93- \\
123\end{array}$ & Rendah & - & - \\
\hline$\leq 92$ & Sangat & - & - \\
\hline Rendah & & $\mathbf{1 0 0} \%$ \\
\hline & & dimlah & atas
\end{tabular}

menunjukkantingkat perilaku prososial siswa kelas VII A di SMP Negeri 22 Kota Bengkulu setelah diberikan layanan bimbingan kelompok meningkat, terdapat enam siswa yang memiliki perilaku prososial yang tergolong sangat tinggi, empat siswa memiliki tingkat perilaku perilaku prososial yang tergolong tinggi dan dua siswa orang siswa yang memiliki tingkat perilaku prososial yang tergolong sedang.

Tabel 3. 
Perbedaan mean pre-test dan post-test perilaku prososial

\begin{tabular}{|c|c|c|}
\hline Keterangan & & \\
\hline $\begin{array}{l}\text { Pre-test } 113 \\
\text { Post-test }\end{array}$ & 156 & $\begin{array}{c}\text { Peningkatan } \\
42\end{array}$ \\
\hline
\end{tabular}

Berdasarkan tabel di atas menujukkan bahwa hasil analisis statistik diketahui ratarata skor prososial adalah sebesar 113 dan setelah diberikan perlakuan sebesar 156. Diperoleh skor ini menunjukkan bahwa terjadi peningkatan skor perilaku prososial sebesar 42 .

Tabel 4.

Kerja UjiWilcoxon

\begin{tabular}{l}
\hline \multicolumn{1}{c}{ Pretest-Posttest } \\
\hline $\mathrm{Z}-3063$ \\
\hline Sig.(2-tailed).002 \\
\hline
\end{tabular}

Uji hipotesis pada penelitian ini menggunakan rumus uji $Z$ atau uji Wilcoxon yang dilakukan untuk melihat nilai antara pretest dan posttest. Uji Z merupakan statistic non-parametrik karena jumlah subjek dalam penelitian ini yaitu 12 siswa kelas VII. A

Berdasarkan tabel 4 kerja uji Wilcoxon menunjukkan bahwa hasil uji hipotesis nilai $\mathrm{z}$ sebesar -3063 dengan nilai signifikan $0,002(\mathrm{p}<0.05)$ sehingga $\mathrm{H}_{\mathrm{o}}$ ditolak. Berdasarkan hasil tersebut dapat disimpulkan bahwa ada pengaruh layanan bimbingan kelompok terhadap perilaku prososial siswa kelas VII.A SMP Negeri 22 Kota Bengkulu.

Perilaku prososial menjadi salah satu hal yang terpenting dalam rentang kehidupan manusia, karena manusia tidak dapat tumbuh dan berkembang dengan baik apabila tidak menerima pertolongan dari orang lain. Hal ini senada dengan penjelasan Gerungan (2010: 26) bahwa manusia secara hakiki merupakan makhluk sosial yang senantiasa memerlukan orang lain untuk dapat memenuhi kebutuhan hidupnya, baik kebutuhan fisiologis maupun kebutuhan psikologis.

Perilaku prososial merupakan perilaku sosial positif yang mendatangkan keuntungan bagi si penerima dengan tujuan untuk meningkatkan kesejahteraannya sehingga kondisi fisik, materil, dan psikis penerima tersebut menjadi lebih baik, hanya saja bagi pelaku tidak begitu tampak keuntungan yang didapatkannya.

Berdasarkan pengujian terhadap hipotesis penelitian, hasilnya menunjukkan bahwa ada perbedaan perilaku prososial siswa sebelum dan sesudah diberikan perlakuan dengan nilai $\mathrm{z}=-3063$ dan signifikansi (2-tailed) 0,002 ( $\mathrm{p}<0,05)$ yang berarti Ho ditolak dan Ha diterima. Maka dapat disimpulkan bahwa terdapat 
pengaruh layanan bimbingan kelompok terhadap perilaku prososial siswa kelas VII di SMP Negeri 22 Kota Bengkulu.

Menurut Prayitno (1995: 178) layanan bimbingan kelompok adalah suatu kegiatan yang dilakukan oleh sekelompok orang dengan memanfaatkan dinamika kelompok, artinya semua peserta dalam kegiatan kelompok saling berinteraksi, serta bebas mengeluarkan pendapat, menanggapi, memberi saran dan apa yang dibicarakan itu semuanya bermanfaat untuk diri peserta dan untuk peserta lainnya. Sebelum diberikan perlakuan perilaku prososial siswa berada pada kategori rendah dan sangat rendah, sedangkan setelah diberikan perlakuan skor perilaku prososial siswa meningkat menjadi kategori tinggi dan sangat tinggi. Berdasarkan hasil data tersebut terjadinya peningkatan perilaku prososial siswa kelas VII SMP Negeri 22 Kota Bengkulu.

Layanan bimbingan kelompok terbukti efektif untuk meningkatkan perilaku prososial siswa. Melalui layanan bimbingan kelompok siswa terdorong untuk mengembangan perasaan, pikiran, persepsi, wawasan, dan sikap yang menunjang diwujudkannya tingkah laku yang efektif (Prayitno, 1995: 78).

Menurut Brigham (dalam Dayakisni \& Hudaniah, 2009: 167) menjelaskan bahwa ada beberapa cara untuk meningkatkan perilaku prososial, salah satunya adalah dengan cara penayangan model perilaku prososial melalui kegiatan belajar sosial terutama dengan cara meniru, dan menekankan pada perhatian terhadap norma-norma tanggung jawab sosial yang dapat ditanamkan oleh orang tua, guru, ataupun melalui media massa.

Materi layanan bimbingan kelompok yang diberikan kepada siswa mencakup lima aspek perilaku prososial tiga di antanya dikemukakan oleh Eisenberg dan Mussen (1989 dalam Dayakisni \& Hudaniah, 2009: 155) dan dua dari Sampson (dalam Darmadji, 2011: 131). Berdasarkan lima aspek inilah disusun dan dijadikan materi layanan agar siswa dapat memahami dan mempraktikkan perilaku prososial yang seharusnya. Pada setiap pertemuan, peneliti selalu memberikan motivasi dan menekankan pada materi yang dianggap penting agar siswa menjadi lebih terdorong untuk melakukan perilaku prososial.

Perilaku prososial siswa secara faktual lebih baik dari kondisi sebelumnya. Hal ini terlihat pada saat ada siswa yang berani mengemukakan pendapatnya sedangkan beberapa siswa yang lainnya mendengarkan dengan baik dan menghargai pendapat temannya yang bersedia 
melakukan simulasi mengenai aspek perilaku prososial ini dimaksudkan agar teman yang lain dapat meniru perilaku yang dicontohkan dan mengaplikasikannya dalam kehidupan sehari-hari.

Menurut teori empathy-altruism hypothesis yang dikemukakan oleh Fultz, Batson, Fortenbech, dan Mccarthy (1986 dalam Dayakisni \& Hudaniah, 2009: 161) bahwa tindakan prososial semata-mata dimotivasi oleh perhatian terhadap kesejahteraan orang lain. Tanpa adanya empati, orang yang melihat kejadian darurat tidak akan melakukan pertolongan.

Hasil penelitian ini senada dengan hasil penelitian sebelumnya yang dilakukan oleh Permata (2003) bahwa layanan bimbingan kelompok cukup efektif untuk meningkatkan perilaku prososial siswa.

\section{Kesimpulan}

Berdasarkan hasil penelitian dapat disimpulkan bahwa perilaku prososial siswa kelas VII di SMP Negeri 22 Kota Bengkulu sebelum diberikan treatment layanan bimbingan kelompok menunjukkan pada kategori sedang dan rendah. Hal tersebut bermakna bahwa perilaku prososial siswa yang masih kurang hal tersebut dapat dilihat dari kerjasama, berbagi, membantu, peduli dan memperimbangkan hak dan kesejahteraan antar sesama teman.

Perilaku prososial siswa kelas VII di SMP Negeri 22 Kota Bengkulu setelah mendapatkan layanan bimbingan kelompok menunjukkan pada kategori sangat tinggi, tinggi dan sedang. Hal tersebut menunjukkan bahwa perilaku prososial siswa baik karena setelah mendapatkan perlakuan berupa layanan bimbingan kelompok hal tersebut menunjukkan terjadi peningkatan.

Layanan bimbingan kelompok berpengaruh terhadap perilaku prososial siswa kelas VII di SMP Negeri 22 Kota Bengkulu. Hal ini dibuktikan dengan uji Wilcoxon dengan nilai $\mathrm{z}=-3063(\mathrm{p}<0.05)$. Ini bermakna bahwa ada pengaruh signifikan dari layanan bimbingan kelompok terhadap perilaku prososial pada siswa kelas VII di SMP Negeri 22 Kota Bengkulu.

\section{Daftar Pustaka}

Baron, R.A., \& Byrne, D.(2005). Psikologi sosial jilid 2 edisi kesepuluh. Jakarta: Erlangga.

Darmadji, A (2011).Prilaku prososial vs kekerasan sosial: Sebuah Tinjauan Pendidikan Islam". Jurnal universitas islam indonesia Vol IV. No.1. dari http//jurnal uji.ac.id diunduh 10 Januari 2017. 
Dayakisni, T., \& Hudaniah. (2009).

Psikologi sosial. Malang : UMM press.

Prayitno, (1995). Layanan Bimbingan dan Konseling Kelompok. Jakarta: Ghalia Indonesia.

Sarwono, S.W (2009). Psikologi sosial. Jakarta: Salemba humanika

Sears, O.S., Freedman,J.L dan Peplau, L.A. (1991) Psikologi Sosial Jilid 2. Jakarta: Erlangga.

Gerungan, W.A. (2010). Psikologi Sosisial. Bandung : PT Refika Aditama. 